NASA Technical Memorandum 101642

AVSCOM Technical Memorandum 89-B-008

\title{
INTEGRATED MULTIDISCIPLINARY DESIGN OPTIMIZATION OF ROTORCRAFT
}

Howard M. Adelman and Wayne R. Mantay 
,-
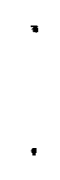
Howard M. Adelman*

Interdisciplinary Research office

NASA Langley Research Center

Hampton, Virginia

and

Wayne R. Mantay*

Aecostructures Di rectorate

USAARTA-AVSCOM

Langley Research Center

Hampton, Virginia

\section{Abstract}

Thl g paper describes a Joint NASA/Aray research actluity at the Langley Research Center to develop optimization procedures almed at lmproving the rotor blade design process by integrating approprlate disciplines and accounting for laportant interactions among the diactplines. The activity is being gulded by a Steering Committee made up of key NASA and Army researchers and managers. The comittee, which has been nawed IRASC (Integrated Rotorcraft Analysis Steering Combittee), has defined two princlpal foci for the activity: a "white paper" which setg forth the goals and plans of the effort; and a rotor design project which will validate the basic constluents, as well as the overall design methodology for multidisc1plinary optimization. The paper describes the optimization formulation in terws of the objective function, design variables, and constralnts. The analysis aspects are discussed, and an initial attempt at defining the interdisciplinary coupling is summarlied. At this writing, some signiflcant progress has been made. Results are given in the paper which represent accomplishments in rotor aerodynamic performance optimization for minimum hover horsepower, rotor dynamle optimization for vibration reduction, rotor structural optialzation for minlmum weight, and Integrated aerodynamic load/dynamics optimization for minturu vibration and weight.

\section{Introduction}

An emerging trend in the analytical design of alrcraft is the integration of all appropriate disciplines in the design process (refg. 1 and 2 ). Th1s means not only including Ilmtations on the degign from the varlous disciplines, but also defining and accounting for interactions so that the disclplines influence design decisions simultaneously tather than sequentially. Because the terms "Integrated" and "disclpline Integration" are frequently used imprecisely, a definition of an Integrated diaciplinary design process is offered. Such a process is integrated if:

(1) Information output frow any disclpline is expeditiously avallable to all other disciplines as required.

(2) The effect of a design varlable change proposed by one discipline on all other disciplines and the system as a whole is made known promptly.

\footnotetext{
* Sentor Research Englneer, Member AIA

* Chlef, Aeromechanics Division, Member AHS
}

Adhering to the above defintelons is central to the plan to be described in this paper. The integrated approach has the potential to produce a better product as well as a better, more systematic design process. In rotorcraft design ( $t$ he rotor in particular), the approprlate disciplines Include aerodynamics, dynamics, structures, and acouatics. The purpose of this paper is to describe a plan for developing the logic elements for helicopter rotor design optimization which includes the above disciplines in an integrated manner.

Rotorcraft design is an 1deal application for integrated multidisclplinary optinization. There are strong interactions among the four disciplines cited previously; Indeed, certain design parameters influence all four disciplines. For example, rotor blade tip speed influences dynanics through the fnertial and alr loadings, structures by the centrifugal loadings, acoustics by local Mach number and air loadings, and aerodynamics through dynamic pressure and Mach number. All of these conslderations are accounted for in current destgn practice. However, the process is usually sequentlal, not simultaneous, and often involves correcting a design late in the design schedule.

Applicationg of rigorous and systematic analytlcal design procedurea to rotorcraft have been Increasing, especlally in the past flve years. Procedures have accounted for dynamics (refs. 3-8), aerodynamlcs (ref, 9), and structures (ref. 10). Generally, these applications have only congldered single-discipline requiresents, although in reference 5, dynawle and structural requirements were considered together, and in reference 6 , dynamics and aeroelastic atability were combined.

In early 1985, several occurrences led to an excellent opportunity at the NASA Langley Research Center to addresa the mulidisciplinary design problem for rocorcraft. The Interdisclplinary Research office was established and charged with the development of Integrated multidiaciplinary optimization methods. Nearly concurtently, the Army Aerostructures Directorate at Langley escablished the goal of Improving rotorcraft design methodology by "disclpline integration." Close cooperation between the NASA and Army organizations led to inftial plans for a comprehensive, integrated analytical design capability. A group of NASA/Army researchers recently formed a committee and began detalled planning for this activ1ty. The committee, designated IRASC (Integrated Rotorcraft Analysis Steering Committee), has now 
completed the bulk of the planning and has formlated the approach described in this paper.

The development of an integrated mitidisciplinary design methodology for rotorcraft is a chree-phased approach. In phase 1 , the diac1plines of blade dynamics, blade aerodynamics, and blade structures will be closely coupled, while acoustics and afrfame dynamics will be decoupled frow the first three but w111 be accounted for by effective constraints on the other disciplines. In phase 2, acoustics will be Integrated with the flrst three disciplines. Finally, in phase 3 , alfframe dynamics will be fully integrated with the other four disciplines. In all three phases, systematically validated methods are the princlpal products of the research.

This paper lo primarily concerned with the phase 1 activity; namely, the rigorous mathematlcal optialzation of a hellcopter rotor syaten to minialze a comblnation of horsepower required at varlous flight conditions and hub shear transmitted from the rotor to the fuselage. The design will satisfy a set of deslgn requirements including those on blade frequencles, autorotational inertla, aerodynamic performance, and blade structural constraints. Additionally, the design is required to satisfy constraints imposed by response of the fuselage and also those constratnts related to acoustics requirements.

\section{General Approach and Scope}

\section{Developwent Strategy}

The general approach for the activity is 1llustrated in flgure 1 . In phase 1 the blade aerodynaml c, dynamics, and structural analyses are coupled and driven by the optimizer. The optintzation of the blade aerodynamlc geometry well as the Internal structure (spar, leading and tralling edge, ballast, etc.) is perforned. The influences of the alrframe dynamcs and blade acoustice are accounted for in terms of design requirements (constralntg) on the blade design. These requirements are described later in the paper. For a check on the efflcacy of representiag the acoustics requirements indirectly, the "final" dealgn will be Input to an acoustics analyala. The acoustics analysis calculates the acoustic response measures and derivatives of these measures with respect to the deaign variables. This inforaation 111 be used to deterad ne how well the design was able to satisfy the actual acoustics design requirements.

The phase 2 procedure, whereln acoustics is fully integrated with the blade aerodynasica, dynamfes, and structural analysis, is also lliustrated in figure 1. The design produced in phase 2 (when converged) wlll satigfy acoustics goals. Aleframe dynamics in phase 2, as in phase 1 , Is accounted for by effective constraincs on the blade dynamics, aerodynamics, and structural behavior. Plnally, in phase 3 alrframe dynamics Is Integrated and the result is a fully integrated optinlzation strategy.

\section{Sequence of Tasks}

Figure 2 deplcts the general sequence of tasks that wlll lead to a fully integrated rotor blade aerodynamic/dynamic/structural optimization procedure which also accounts for acoustic and alrframe dynamlc Influences. The dynamic optimization work is bullding on the work described in references 5-7. The rotor aerodynamics activity has been separated into two parts. The flrst is aerodynamic performance optimization which is a continuation of the work described in reference 9. The second is an integration of aerodynamlc loads analysis with dynamics - a procedure whereln the local alrloads can be adjusted by varying the planform dimensions and twist of the blade to reduce dynawlc response. A wer of the rotor performance optimization with the alrload/dynamics optimization will yleld a fully integrated aerodynamic/dynamlc procedure. The rotor atructural optialzation is a continuation of the work of reference 10. A werger of all the aforementloned procedures, with the acoustic and altframe constraints interfaces, will lead to the fully Integrated Phase 1 procedure. The resuleling capability will be applied to a rotor test article to validate the procedures.

\section{Overall Problem Formulation}

This section of the paper consists of detalls of the integrated rotorcraft optimization problem. Included are descriptions of the following: the objective function (the quantity to be minimized for obtaining an optimum degign); the design variables (dimensions and other parabeters of the desiga); constraints (a set of behavioral or characterlatic limtations required to assure acceptable and safe performance); and definitions of the interactions asong the disciplines.

\section{Objective Funcelon}

The objective function will consist of a combination of the maln rotor horsepower at five flight conditions plus a measure of vibratory shear transwitted from the rotor to the hub. Although several witiple objective function techniques are avallable (ref. 11) one leading candidate is a Inear combination whereby

$$
\begin{aligned}
F= & k_{1} \mathrm{HP}_{1}+k_{2} \mathrm{HP}_{2}+k_{3} \mathrm{HP}_{3} \\
+ & k_{4} \mathrm{HP}_{4}+k_{5} \mathrm{HP}_{5}+k_{6} \mathrm{~S}
\end{aligned}
$$

where $P$ is the objective function

$k_{1}$ through $k_{6}$ are welghting factors

$\mathrm{HP}_{1}$ through $\mathrm{HP}_{5}$ are required horsepower at vartous flight conditions

$S$ Is the vertical hub shear

A candidate set of flight conditions would be: 


\begin{tabular}{cccc}
$\begin{array}{c}\text { Flight } \\
\text { condition }\end{array}$ & Descrlption & $\begin{array}{c}\text { Velocisy } \\
\text { (kts) }\end{array}$ & $\begin{array}{c}\text { Load } \\
\text { factor }\end{array}$ \\
\hline 1 & Hover & 0 & 1.0 \\
2 & Crulse & 140 & 1.0 \\
3 & High speed & 200 & 1.0 \\
4 & Maneuver & 120 & 3.5 \\
5 & Climb & $1000 \mathrm{fpw}$ & -
\end{tabular}

Blade Model and Deslgn Variables

Figure 3 is a depiction of the rotor blade model to be used in the phase 1 optinlzation activity. Also shown in figure 3 are the design varlables which are defined in table 1 . The blade model may be tapered $1 \mathrm{a}$ both chord and depth. The depth is linearly tapered frow root to tip. The chord is constant from the root to a spanwise location (referred to as the point of taper inftia$t(0 n)$ and may be Ilnearly tapered thereafter to the tip. Design variables which characterlze the overall geometry of the blade include the blade radius, point of taper intelation, taper ratlos for chord and depth, the root chord, the blade depth at the root, the flap hinge of fset, and the blade maximum twist. Tuning masses located along the blade span are characterized by the mass values and locatlons. Destgn varlables whlch characterlze the spar box beam cross section include the wall thlcknesses at each spanwise segment and the ply thickness at $0^{\circ}$ and $\pm 45^{\circ}$. Additional design varlables include the number of rotor blades, the rotor angular speed, and the distribution of alrfolis.

\section{Constraints}

As previously described, the phase 1 activity is based on lntegrating the blade aerodynamic, dynamlc, and structural analyses within the optialzation procedure. The acoustics and alrframe dynamics analyges are decoupled from the flrot three disciplines and their influences are expressed in terms of constralnts. Accordingly, the set of constraints 1a made up of two subsets. The flrst subset consists of constraints which are evaluated directly from the first three disciplinary analyses and are a measure of the degree of acceptabliity of the aerodynamlc, dynamlc, and structural behavior. The second subset represents Indirect measures of the satiafaction of constraints on the acoustics behavior and the requirement of avolding excessive vibratory excltation of the alfframe by the rotor.

The constraints are summarlzed in table 2 . The first two constraints are for aerodynamic performance and require that for all fl1ght conditlons, main rotor horsepower not exceed avallable horsepower and that alrfoll section stall not occur at any azimuthal locatlon. The next nine constraints address blade dynanics. The first requires that the blade natural frequencles be bounded to avold approsching any mittples of rotor speed. The next flve Impose upper 1 imits on the blade vertical and Inplane loads, trangmitted hub shear, hub pitching, and roliling moments. The next three dynanlc constraints are an upper limit on blade response amplitude, a lower linit on blade autorotat lonal inertia, and flnally, the aeroelastic stablifey requirement. The structural constralnts consist of upper limits on box beam stresses, blade static deflection, and blade twist deformation. The acoustic constralnts are expressed as an upper bound on the tip Mach number and an upper bound on the blade thlckness to 11 mit thickness nolse; and an upper bound on the grad1ent of the lift distribution to limit blade vortex Interaction (BVI) and loading nolae. The airframe constralnts are expressed first as a separation of the fundamental blade inplane natural frequency in the flxed system from the fundamental pitching and rolling frequency of the fuselage to avold ground resonance; second as a bounding of the blade passage frequency to avold the proximity to any fuselage frequency.

\section{Interdisciplinary Coupling}

Phase 1 of the effort will utllize several design varlables which have historlcally been slgniflcant drivers of disciplinary phenomena. In addition, other variables are being included to provide other unexplored design opportunitles. Table 3 shows an at tempt to characterize the interactions among the disciplines through the design varlables. For example, rotor tip speed has driven past rotor designs based solely on acouat 1c8, performance, or dynamics. This var1able also influences blade structural integrity and flxed system reaponse to transwitted loads. This provides the strong interdisclplinary coupling for tip speed shown in table 3. There are varlables, such as blade twigt, which can atrongly Influence some disclplines, such as aerodynamics, while not perturbing others (e.g., structures) and other variables such as a hinge offset which, heretofore, have not greatly influenced conventional rotor design.

A signiflcant part of the current effort w11l not only explore the obvious strong design variable couplings, but will also address those vartables which may provide design synergisw for multidisciplinary design goals. This may provide a design key for missions which have not been accomplished with today'g rotorcraft.

\section{Implement ation Method}

\section{Organization of System}

The overall organization of the system to optinlze a blade deslgn for aerodynamics, dynamlcs, and structural requirements 18 shown schematicaliy In figure 4. In order to perform the aerodynamic, dynamic, and atructural analyses lndicated in the blocks in flgure 4, it is first necessary to transfora or "pre-process" the design vartables into quanticles needed in the various analyses. For xample, the dynamlc and structural analyses both need st $1 \mathrm{f}$ nesses EI and $G J$, and laminate properties. The aerodynamic analyais needs lift and drag coefficlents for the alrfolls used. The above Information is obtained by the design variable pre-processors which act as translators of the global design variables into local variables needed in the analyses. The output of each analysis block, in general, serves two purposes. PIrst, response-type output may be transulted to another analgsis block (e.g., alrloads from aerodynamics to dynamics); second, Information is supplied to the objective function and constraints 
block (e.g., stress congtralnts from the structural analysis). A key part of the procedure $1 \mathrm{~s}$ the sensitivity analysis. Th1s block corresponds to the calculation of derivarives of the constraints and objective function with respect to the design varlables. The derivatives quantify the effects of each design variable on the design and, thereby, Identify the most important design changes to make enroute to the optimum design.

The senstelvity information is passed to the optimizer along with the current values of the design varlables, constralnts, and objective function. The optinizer uses the information to generate a new set of design varlables, and the entire procedure 18 repeated unt 11 a converged design ls obtalned. For our purposes, a design 18 converged when all constralnts are satisfled and the objectlve function has reached a value which has not changed for a spectfled number of cycles.

\section{Optimlzation Algortthm}

The basic optimization algorlthm to be used in this work is a combination of the generalpurpose optimization program CONMIN (ref. 12) and approximate analyses for computing the objective function and constraints. Because the optimization process requires many evaluations of the objectlve function and constraints before an optimum design is obtalned, the process can be very expensive if complete analyses are made for each function evaluation. However, as Miura (ref. 3) points out, the optinization process primartly uses analysis results to move in the direction of the optimum design; therefore, a complete analysis needs to be made only occasionally during the design process and always at the end to check the final design. Thus, various approximation techniques can be used during the optialzation to reduce costs. In the present work, the obfective function and constrainte w111 be approximated using plecewise linear analyses that consist of linear Taylor series expansions.

\section{Analyglo Aspects}

The analycical tools mat provide techinical fidelity in phenomeno predictions, as well as connectivity between disclplines. The areas of aerodynamics, dynamics, and structures 111 utflize codes to predict response, as well as sensitivity information. The conatraint-providing disciplines of acoustics and alrfrase dynand cs have the analysis taok of defining the Impact of the design on acoustic energy and fuselage response.

The aerodynanlc analysis for rotor performance prediction will include a hover mobentua/ strip theory code for hover and cliab applicarlons (ref. 13). The CAMRAD program (ref. 14) will be used for forward flight and waneuver performance. In order to assure that the lateat developments in Inflow analyses are avallable, some modularity will be provided in the inflow modeling based on recent fidelity assessments.

Rotor dynamics will utillze CAMRAD for forced response calculatlons. Finfte element modeling (ref. 15) and the modifled Galerkin technlque in CAMRAD will form the tools for the dynamic tuning before the global analysis predicts the final blade loads, response, and rotor stability.

The structural codes involve a combination of beam analysis and laminate analys 1s. The analysis (e.g., ref. 10) 1g applied to the blade planform model. The laminate analysis will be applied to one or more cross-section models. The beaw model consists of equivalent stiffness and masses from which displacements and forces are computed. The Internal blade atructure is represented by crosasection wodels to calculate resultant stresses assoclated with each bean model segwent. The laminate analysis then uses these stresses to determine critical structure margins of safety.

The effectiveness of 1mposing phase 1 acoustic constraints will be quantifled by using the WOPWOP code (ref. 16), with appropriate loading lnputs from CAMRAD. Low frequency loading, thickness, and BVI nolse w111 be generated from this analyols.

Aiframe dynamics constralnts for phases 1 and 2 will result from fixed-system frequency predictlons and will neglect hub motlon. Phase 3 of the effort will Involve finite element modeling and Impedance talloring to effect favorable rotorbody coupling in the design process.

\section{Validation Strategy}

\section{Valldation of Procedures}

The process of validating the optiafzation methodology involves substantially more than evaluatiog the auccess of the final design. Specifically, the analyses used in optimizing the rotor during Phase 1 will be examined for predictive fidelity and design technique validation. The usefulness of the basic tools involves not only accuracy of analyals, but also a rellable parametrlc senaltivity capablity. Several opportunitles are currently avaliable to assess the fidelfty of the analyses. For example, rotor performance, dynamlcs, and acoustics predictions need accurate Inflow distributions for various flight conditlons. Recent experimental efforts (e.g., ref. 17) and code validations (ref. 18) are helpIng to provide confidence in the avallable inflow models. Rotor geosetric design variable sensitivity (e.g., effect of taper on performance), which was reasonably well-known for past rotor dea1gna, lo beling re-exand ned in $11 \mathrm{ght}$ of recent correlation anomiles for high-speed flight. Acoustic source wechanlsas and modeling validity are also belag examined (ref. 19), especially for paranetric sensitivity of the acoustic energy to rotor state. Structural coupling wechanlcs are belag explotted In new rotor designs to assess the structural talloring benefits while satisfying structural Integrity requirements (ref. 20 ).

Proof of the Eldelity of design techniques is crucial to the overall design optinization ef fort. For example, aerodynanics and dynanice Interact so atrongly in rotor design that basic aeroelastic tallorling efforts ant be validated. Such a validation effort is being undertaken at Langley, as well so other research centers (ref. 21). Also, because rotor speed is atrong driver for aeroelastic response, program to assess varlable RPM designs is underway at Langley. The objective of 
this effort is to define the benefits and limitatlons of an aerodynamically and dynamically designed rulti-speed rotor. In additton to design techniques which capitalize on the strong effects of certain design varlables, small vartances in other blade characteristics may lmpede the practical operation of even conventional designs. Hence, the ablilty to accurately predict even these secondary phenomena is Important for the design effort. For example, track-and-balance sens1tivity experiments and studies are belng undertaken which can lead to practical design capability to eliminate blade-to-blade varlability effects.

\section{Overall Design Validation}

For the overall phase 1 valldation effort, the langley team is defining a rotor task which requires maneuverabllity, speed, and efficlency (see table 4). Speciflcally, the rotor of ssion must be accomplished with winimum power and vibration while satisfying predefined acoust1c, stablitty, and fuselage dynamics requlrements. This validation activity is, in effect, a design project which will produce a rotor test article.

The assessment of the phase 1 design methods will Involve model rotor hover and wind tunnel tests. The models (a baseline and an advanced design) will be aerodynamically and dynamlcally scaled. Provisions for varying key design paraweters are necessary to complete the valldacton process. In other words, the tests need to quantify not only the minima, but the gradients. The testing posstblittes include a serles of $1 / 5-s c a l e$ model rotors, mounted on a variable drive system and tested in hover and simulated forward flight in a tunnel which can ellainate many testing "excuses" such as Inappropriate Reynolds, Mach, and Froude Numbers. The Langley TDT is the candidate facility for the mafor segments of the validation process.

\section{Results Obtalned to Date}

Progress has been made in the areas of aerodynamic performance optimization, optimum placement of tuning masses for vibration reduction, structural optinization, and integrated aerodynamic load/dynamic optimization. Selected results from these activities are highlighted in this portion of the paper.

\section{Results - Aerodynamic Performance Optinization}

A Mathematical Programing technique (ref. 9) has been developed to miniolze the hover horsepower for a helicopter with a speclfled design gross welght operating at a specifled altitude and temperature (fig. 5). A conventional design approach is usually a two-step iterative method. The flrgt step is design for optlmum hover performance by varying taper rat10, point of taper Inltiation, and twist unt1l the rotor blade configuration with the lowest hover horsepower is obtalned. In the second step, this best hover design is modifled by changing the root chord to weet forward flight and maneuverablilty requirements. The Mathematical Programing approach used the same performance analyses as the conventional approach, but coupled a general-purpose optiniza- tion program to the analyses. The conventional and Mathematical Programing approaches have been used to define the blade configuration which provides the lowest hover horsepower and satisfles forward flight and maneuverability requlrements. Flgure 5 gummarlzes results for the final design vartable values and the maln rotor horsepower required for hover from each approach. The Mathematlcal Programming approach produced a design with more twist, a polnt of taper Initlation further outboard, and a smaller blade root chord than the conventional approach. The Mathematical Programming design required 25 less hover horsepower than the conventional design. Most signifIcantly, the Mathematlcal Programming approach obtalned results more than ten times faster than the conventional approach.

Results - Optimum Locations of Vibration Tuning Masses

The objective of this work (described in ref. 22) is to develop a method for optimally locating, as well as sizing, tuning masses to reduce vibration using formal wathematical optinization techniques. The design goal is to find the best combination of tuning wasses and thelr locations to rinlmize blade root vertical shear without a large mass penalty. The method is to formulate and solve an optlalzation problem in which the tuning wasses and their locations are design varlables that minimize a combination of vertical shear and the added mass, with constraints on frequencles to avold resonance. Figure 6 shows an arbitrary number of masses placed along the blade span. The optimlzation strategy reduces the oscillatory shear as a function of tise during a revolution of the blade.

Results have been obtalned wherein the above strategy was applied to a rotor blade considering multiple blade mode/multiple harmonic alrloads. The example problew is a beam representation of an articulated rotor blade. The beam is 193 inches long with a hinged end condition and 15 modeled by 10 finfte elements of equal length. The model contalns both structural wass and lumped (nonstructural) mases. Three lumped mases are to be placed along the length of the beam. The strategy was applied to a test case of two modes responding to three harmonics of alrload. Figure 7 shows for the initial and final designs, the shear $s$ plotted as a function of the time and azluth for one complete revolution of the blade. The peaks on the initial curve have been reduced dramatically. For example, the maximum peak oscillatory shear for the Inftial design is $78.001 \mathrm{bf}$, and for the flnal design, the aximum peak is 0.60 lbf.

\section{Results - Rotor Structural Optimization}

A blade structural optimlzation procedure applicable to metal and composite blades has been developed in which the objective function is blade mass with constraints on frequencles, stresses in the spars and in the skin, twiat deformation, and autorotational inertia. The design variables (f1gure 8 ) are the total spar thlckness and for the composite blade the percentage of $\pm 45^{\circ}$ plies (the remalning plies are assumed to be at $0^{\circ}$ ). This procedure and additional applications of the method are given in reference 10 . 
This section describes two example rotor blade deslgns which were developed using the structural design methodology. Both designs are based on the UH-60 Black Hawk blade. The flrat design 13 for a ticanium single spar cross section. The second case has a graphlte/epoxy spar In a single spar cross-gection configuration. The composite spar design la compared to the metal spar design to explore potential weight savings obtained frow uge of the design methodology in confunction with composite materials.

Titanium crogs section.- For the titanium spar blade, the cross-section model was based on the UH-60 rotor blade with identical skin, core, tralling edge tab, leading edge welght, and spar coordinates. Only the spar thickness was used as a design varlable. The beam model representation of the blade used a rectangular planform similar to the UH-60 planform, but without any tip sweep. A maximum elastic torsional deformation of $3.1^{\circ}$ is based on an effective aerodynamic performance constraint (ref. 10). The structural constraint requires that the calculated stresses do not exceed the allowable materlal strength based on the Tsal-Hill fallure criterion. The autorotational capability 18 assumed to be the same for this design as it 18 for the UH-60. Autorotation 1a satisfled by requiring the mass moment of Inertia to be Identical to that of the UH-60 rotor system whlch is 19000 1n-1bs-s per blade. Before a structural comparison to the UH-60 blade can be made, the design had to be dynamically tuned. The modes considered In this design were first elastic flapwise and edgewise bending, firgt torsion, and second and third flapwlse bending. The frequencles of these wodes were required to be removed from integer wultiples of the forcing frequency by 0.2 per rev.

As shown in figure 8, the minfwum spar thickness needed to sat 1 fy all the constralnts was 0.130 Inch which corresponds to a blade weight of 207 pounds. The actual UH-60 titaniun spar is 0.135 inch thick, producing a 210 pound blade. The titanium spar design 18 only 3 pounds different from the actual UH-60 blade, demonstrating that the wechanics of the deslgn methodology can produce blade designs bimilar to conventional design processes.

Compostte cross section.- A second design was developed using a single T300-5208 graphite/epoxy D-spar. The blade models and asooclated design assumptions used In the composite design were the same as those used for the wetal spar except for the spar matertal. Here, thickness and ply orientation of the composite apar were used as design variables. The plies of the spar were assuned to consist only of $0^{\circ}$ and $\pm 45^{\circ}$ angleg symetrically bullt up. Thus, the ply ortentation design var1able was the percentage of $\pm 45^{\circ}$ plles in the laminate. The remaining plies of the laminate are understood to be orlented at $0^{\circ}$. Constraints on twist deformation, waterial etrength, mass moment of Inertia, and dynamlc tuning were the same as those used for the metal dealgn.

Results shown in figure 8 show that the cow posite design satiofled the required constralnts. Further, the mintwum weight design had 0.105 Inch thick spar with 20 percent of the plies orlented at $\pm 45^{\circ}$ degrees which resulted in blade welght savings of 21.5 percent. These results demonstrate that this design methodology, used in conjunction with composite materials, can result in signiflcant welght savings.

$\frac{\text { Regults - Integrated Aerodynamic Load/Dymamic }}{\text { Optimization }}$

In reference 23 , an Integrated aerodynamic load/dynamic optimization procedure was developed. The procedure minimized blade welght and $4 / \mathrm{rev}$ vertical hub shear for a rotor in forward flight. The coupling of aerodynamics and dynamics was accomplished by the Inclusion of alr load calculations Inside the optimization loop wherein the afr loads varled with design varlables. The design model used for this procedure 18 the same as that In figure 3. The design variables include the stiffnesses El for spanwise and chordwise bending, the torsional GJ, the taper ratio, the root chord, radius of gyration, and nongtructural masses at each spanwse location. The constraints Include upper and lower bounds on the first four erequencles, a lower bound on autorotational iner$t \mathrm{ia}$, and an upper bound on centrlfugal stress. Both single and wultiple objective function formulationg were used and compared. In the single objective function formulationa, blade weight and 4/rev shear were each Individualiy minimized. For the multiple objective function formulation, a combination of the weight and shear was minimized by use of the Globel Criteria Approach (ref. 11).

A flow chart showing the logic of the optinization procedure is ahown in figure 9. The process is Inttiated by evaluating the preasalgned parameters (those whlch are constant during the optialzation). The next step is to initlalize the design variables and perform the blade structural analysis to calculate the blade properties, the centrifugal stress and the autorotational inertia. The aerodynamic and dynamic response analyses are performed next using CAMRAD. CAMRAD is used to calculate the section loads from the alrfoll twodimensional aerodymanic characteristics. Lifting Iine theory is ued with corrections for yawed and three-dimenstonal flow effects. The blade is trlumed at each pass through the optimization loop using the wind tunnel trit option. The dynatc analysis in CAMRAD Includes calculations of the frequencles and mode shapes (using a modifled Galerkin technique) and the calculation of the 4 /rev vertical shear at the hub. A sensitivity analysis calculates derivatives of the objective function and the conetraints with respect to the design variables. Analytical derivatives are used for the welght, autorotational Inertia and centrifugal stress. Forward finted differences are used for the derivatives of the hub shear and the frequencies. Once the sensitivity analysis 18 completed, the optialzer 18 called to update the dealgn variables.

The above procedure has been applied to a wodel of the Growth Black Hawk rotor blade (see reference 23 for detalls of this mode1). The baseline (analytical) model is linearly tapered from root to tip with a taper ratio of 3.0 , has elght structural nodes, 14 aerodynamica segments, and a single alrfoll for all segments. The alrcraft is in forward flight with an advance ratio of 0.3 . Figure 10 presents comparisons of optimum welght and vertical shear from the three formulatlons. Figure 10 a compares the blade welght and 
figure lab compares the $4 /$ rev vertical shear. Ag shown in the flgure, the Global Crlterla Approach provides the lightest blade structure with a signiflcant hub shear reduction. This is contrary to the intultive belfef that the use of a mitiple objective formulation should yfeld solutions lying between those of the single objective formulatfons. In other words, the blade welght obtained by simultaneously minimizing welght and hub shear might be expected to be higher than that obtained from welght minfmization and the hub shear obtalned should be higher than that obtalned from hub shear minimization. However, this is only true if the objective functions are monotonically tncreasing functions of the design varlables. This is not true in the present case since, for example, the blade welght can decrease with an increase in taper ratio and the hub shear is a very complicated and nonmonotonic function of the design varlables.

It was of Interest to determine the extent to which the optimization process reduced the osc11latory alrloads. To this end, distributions of vertical osctllatory alrloads before and after optimization are compared. Figure 11 shows az1muthal distributions of vertical alrloads for the initial (reference) design and for the three optimum designs at a radial station of 0.75 of the blade span. All three optimization results indicate a significant reduction in oscillatory airload amplitudes. The largest reduction occurred for the third formulation. As pointed out in reference 23, this is a signiflcant finding and Indicates that the optimization process 18 able to adjust the vibration levels downward not only by Erequency placement and modal shaping but also by adjusting alrload distributions in a Eavorable manner.

\section{Concluding Remarks}

This paper has described a foint activity Involving NASA and Arwy researchers at the NASA Langley Research Cencer to develop optinlzation procedures almed at improving the rotor blade design process by Integrating appropriate disc1plines and accounting for all of the Important interactions among the disciplines. The disciplines involved Include cotor aerodynamlcs, rotor dynamics, rotor structures, airframe dynanlcs, and acoustics. The work is focused on combining the five key disciplines listed above in an optiolzation procedure capable of destgning rotor syaten to satisfy multidisciplinary design requirements.

Fundamental to the plan 18 a three-phased approach. In phase 1, the disciplines of blade dynamics, blade aerodynamics, and blade structure will be closely coupled, while acoustics and alrframe dynamics w1ll be decoupled and be accounted for as effective constraints on the design for the first three disciplines. In phase 2, acoustics is to be Integrated with the flrst three disciplines. Finally, in phase 3 , atefrawe dynamics will be fully integrated with the other four disciplines.

This paper dealt primarlly with the phase 1 approach. The paper included: the optinization formulation, design variables, constraints, and obfective function, as well as discipline interactIons, analysis methods, and methods for validatIng the procedure. The paper described how the acoustics and afrframe dynamlcs behavlors are incorporated as constraints into the design procedure. For example, acoustics lmposes a local Mach number constratnt on the blade velocity and angle of attack; and affframe dynamics imposes constraints on the rotor blade natural frequencles to avold ground resonance through coalescence of blade and alrframe frequencles. The plan for validating the components of the design process was described and the strategy for overall validation of the deslgn methodology was defined. These validations are critical to the success of the activity and are vlewed as the primary products of the work. Finally, some representative results frow work performed to date are shown. These Include aerodynamic optimization reaults for performance, optimal placement of tuning mass for reduction of blade shear forces, blade structural optimization for welght minfmization subject to strength constraints, and lntegrated alrload/ dynamic optimization results for vibration reduction.

The results of the individual optimization procedures demonstrate the potential of optimlzation in design of future rotorcraft, both from the standpolnt of efficlency of the process as well as potentially 1mproved products. The results of the integrated alrload/dynamlc optimization procedure demonstrates that there are significant benefits awating analytical designers who pursue interdisciplinary design approaches.

\section{References}

1. Ashley, R.: On Making Th1ngs the Best - Aeronautical Use of Optiolzation. AIAA Journal of Alrcraft, vol. 19, no. $1,1982$.

2. Sobleszczansk1-Soblesk1, J.: Structural Opt1wization Challenges and Opportunities. Presented at International Conference on Modern Vehicle Design Analysis, London, England, June 1983.

3. Miura, H.: Application of Numerlcal Optimization Methods to Hellcopter Design Problems: A Survey. NASA TM-86010, October 1984.

4. Bennett, R. L.: Application of Optimlzation Methods to Rotor Deslgn Problems. Vertica, vol. 7 , no. 3, 1983, pp. 201-208.

5. Peters, D. A.; Rossow, M. P.; Korn, A.; and Ko, T.: Design of Hellcopter Rotor Blades for Optimum Dynamic Characteristics. Computers and Mathematics With Applications, vol. 12A, no. 1,1986 , pp. 85-109.

6. Frledmann, P.: Application of Modern Structural Optiolzation to Vibration Reduction in Rocorcraft. Vertica, vol. 9, no. 4, 1986 , pp. 363-376.

7. Chat topadhyay, AdIt1; and Walsh, Joanne L.: Minimum Welght Design of Rotorcraft Bladeg With Multiple Frequency and Stress Constraints. Proceedings of the AIAA/ASME/ ASCE/AHS 29th Structures, Structural Dynamics and Materials Conference, WIIllamsburg, VA, Apr11 18-20, 1988. AIAA Paper No. 88-2337CP. Also avallable as NASA TM-100569, March 1988. 
8. Davis, M. W.: Optlaization of Hellcopter Rotor Blade Deslgn for Minfmum Vibration. NASA CP-2327, Part 2, September 1984, Pp. 609-625.

9. Walsh, J. L.; Bingham, G. J.; and Riley, M. F.: Optinization Methods Applied to the Aerodynamic Design of Hellcopter Rotor Blades. Journal of Aaerican Hellcopter Soclety, October 1987, pp. 39-44.

10. Nixon, M. W.: Prelloinary Structural Design of Composite Main Rotor Blades for Minlmum Welght. NASA TP-2730, July 1987.

11. Rao, S. S.: Multiobjective Optimization in Structural Design with Uncertain Parawecerg and Stochastic Processes. AIAA Journal, Vol. 22, No. 11, November 1984.

12. Vanderplaats, G. N.: CONMIN - A Fortran Program for Constralned Function Minimization. Uber's Manual. NASA IMX-62282. August 1973.

13. Gessow, Alfred; and Myers, Garry C., Jr.: Aerodynamics of the Hellcopters. Frederlck Unger Publishing Company, New York, 1952.

14. Johnson, Wayne: A Comprehenstve Analytical Model of Rotorcraft Aerodynamics and Dynamics. NASA TM 81182, 1980.

15. Whetstone, W. D.: EISI-EAL Engineering Analysis Language Reference Manual. Engineering Information Systems, Inc., San Jose, CA, 1983.

16. Brentner, R. S.: Prediction of Hellcopter Rotor Discrete Frequency Noise - A Computer Program Incorporating Realistic Blade Mot Lons and Advanced Acoustic Forwulation. NASA TH-87721, October 1986.

17. Ellfott, J. W.; Althoff, S. L.; and Salley, R. H.: Inflow Measurewent Made with a Laser Velocimeter on a Hellcopter Model in Porward Flight. NASA TM-100541, Apr11 1988.

18. Berry, J. D.; Hoad, D. R.; Elllott, J. W.; and Althof f, S. L.: Hellcopter Rotor Induced Velocities Theory and Experiment. American Helicopter Soctety Speciallats Meeting on Aerodynamics and Aeroacoustics, Forth Worth, TX, February 1987.
19. Caradonna, F. X.; Lautenschlager, J. L.; and Silva, M. J.: An Experimental Study of RotorVortex Interactions. Preprint from AIAA 26rh Aerospace Sciences Meeting, January 1988.

20. Lake, R. C.; and Nixon, M. W.: Results From a Prelininary Investigation of Finfte-Element Modeling In Analysis of Composite Rotor Blades. Second International Conference on Rotorcraft Basic Research, February 1988.

21. Weller, W1111am H.; and Davis, Mark W.: Experimental Verlfication of Helfcopter Blade Designs Optinized for Minimum Vibration. Proceedings of the 44th Annual Forum of the American Helicopter Society, Washington, $D C$, June 1988.

22. Pritchard, J. I.; and Adelman, H. M.: Optimal Placewent of Tuning Masses for Vibration Reduction in Hellcopter Rotor Blades. Presented at the Second International Conference on Rotorcraft Basic Research, College Park, Md., February 1988.

23. Chat topadhyay, Ad1t1; Walsh, Joanne L.; and Riley, Michael P.: Integrated Aerodynamic/ Dynanic Optinization of Hellcopter Rotor Blades. NASA TH-101553, Feb. 1989.

TABLE 1 SUMMARY OF DESIGN VARIABLES

\begin{tabular}{|c|c|}
\hline Description & Symbol \\
\hline $\begin{array}{l}\text { Tuning mass at location } 1 \\
\text { Spanwise location of } 1-t h \text { mess } \\
\text { Wing box dimensions } \\
\text { Ply thicknesses } \\
\text { Depth of blade at root } \\
\text { Ratlo of blade depths at tlp and root } \\
\text { Maximu pre-twist of blade } \\
\text { Percent blade span where taper begins } \\
\text { Blade root chord } \\
\text { Alrfoll distribution } \\
\text { glage of feat } \\
\text { Blade angular velocity } \\
\text { Number of blades on rotor } \\
\text { Blade radius } \\
\text { Ratlo of root chord to tip chord }\end{array}$ & 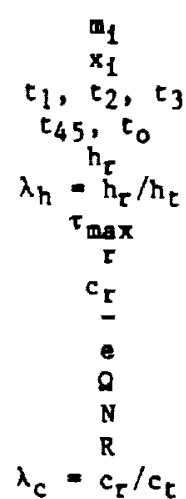 \\
\hline
\end{tabular}


TABLE 2 SUMMARY OF CONSTRAINTS

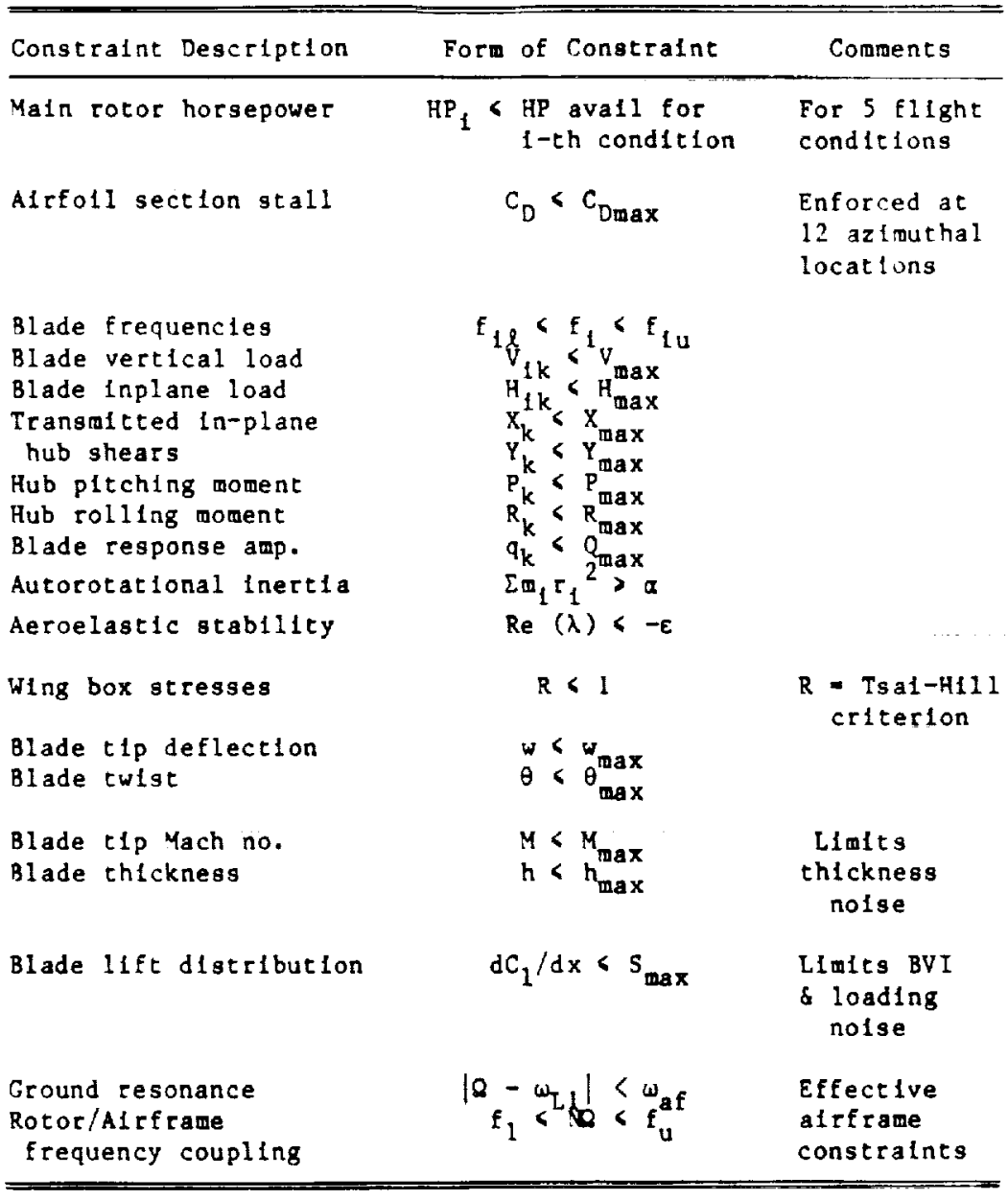

TABLE 3 INTERACTIONS AMONG DISCIPLINES

\begin{tabular}{lccccc}
\hline \hline Variable & Acoustics & $\begin{array}{c}\text { Aerodyn. } \\
\text { (Perf \& Loads) }\end{array}$ & Dynamics & Structures & $\begin{array}{c}\text { Fuselage } \\
\text { Dynamics }\end{array}$ \\
\hline Airfoll Dist. & $\mathrm{S}$ & $\mathrm{S}$ & $\mathrm{W}$ & $\mathrm{W}$ & $\mathrm{W}$ \\
Planform & $\mathrm{S}$ & $\mathrm{S}$ & $\mathrm{S}$ & $\mathrm{S}$ & $\mathrm{S} / \mathrm{W}$ \\
Twist & $\mathrm{W}$ & $\mathrm{S}$ & $\mathrm{S}$ & $\mathrm{W}$ & $\mathrm{W}$ \\
Tip speed & $\mathrm{S}$ & $\mathrm{S}$ & $\mathrm{S}$ & $\mathrm{S}$ & $\mathrm{S}$ \\
Blade number & $\mathrm{S}$ & $\mathrm{W}$ & $\mathrm{S}$ & $\mathrm{W}$ & $\mathrm{S}$ \\
Stiffness & $\mathrm{W}$ & $\mathrm{S}$ & $\mathrm{S}$ & $\mathrm{S}$ & $\mathrm{S} / \mathrm{W}$ \\
Mass dist. & $\mathrm{W}$ & $\mathrm{W}$ & $\mathrm{S}$ & $\mathrm{S}$ & $\mathrm{S} / \mathrm{W}$ \\
Hinge offset & $\mathrm{W}$ & $\mathrm{W}$ & $\mathrm{S} / \mathrm{W}$ & $\mathrm{W}$ & $\mathrm{S} / \mathrm{W}$ \\
\hline \hline
\end{tabular}

S = Strong interaction

$W$ - Weak Interaction 
TABLE 4 CANDIDATE TASK AND MISSION FOR PHASE I DESIGN ACTIVITY

\begin{tabular}{ll}
\hline \multicolumn{1}{c}{ Description } & Specification \\
\hline Condition & $4000 \mathrm{ft} 95^{\circ}$ \\
Alrcraft grobs welght & $16875 \mathrm{lb}$ \\
Installed power limit & $3400 \mathrm{HP}$ \\
Vcrulse & $140 \mathrm{kts}$ \\
V max & $200 \mathrm{kts}$ \\
g's at 120 kts & 3.5 \\
Vertical rate of climb & $1000 \mathrm{fpm}$ \\
Alrframe structure & $\mathrm{UH}-60 \mathrm{~B}$ \\
\hline \hline
\end{tabular}

other constralnts and guldelines are spectefed in table 2 .

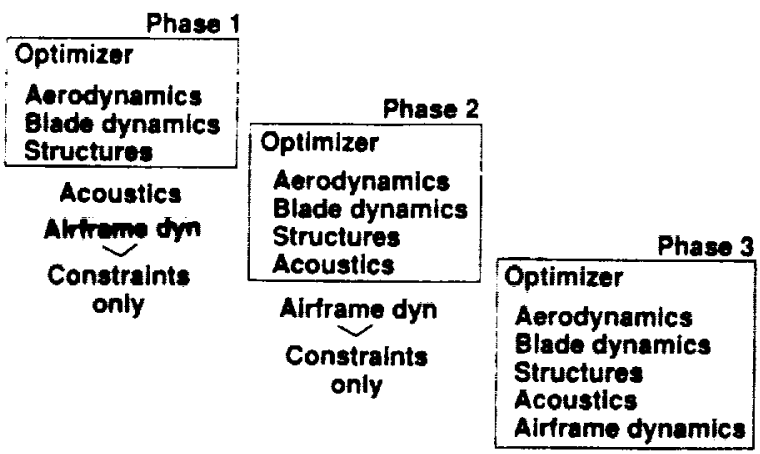

F1g. I Phased approach to development of integrated rotorcraft optimization procedures.

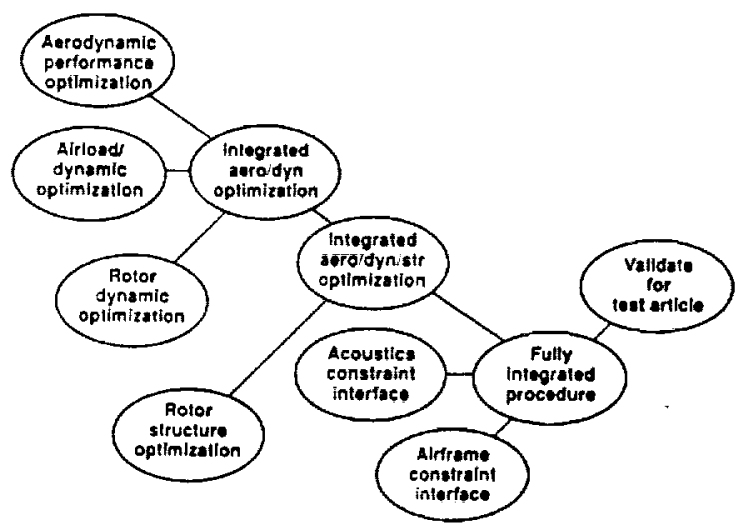

F1g. 2 Integrated rotorcraft optimization development plan.
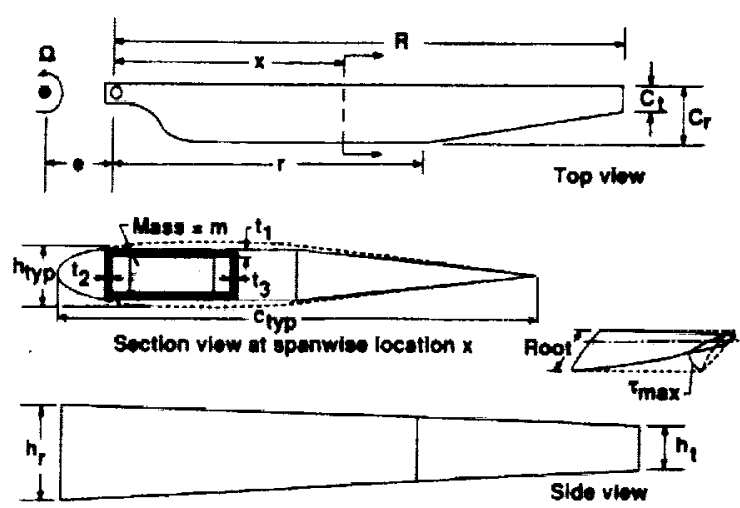

Fig. 3 Blade model and design varlables.

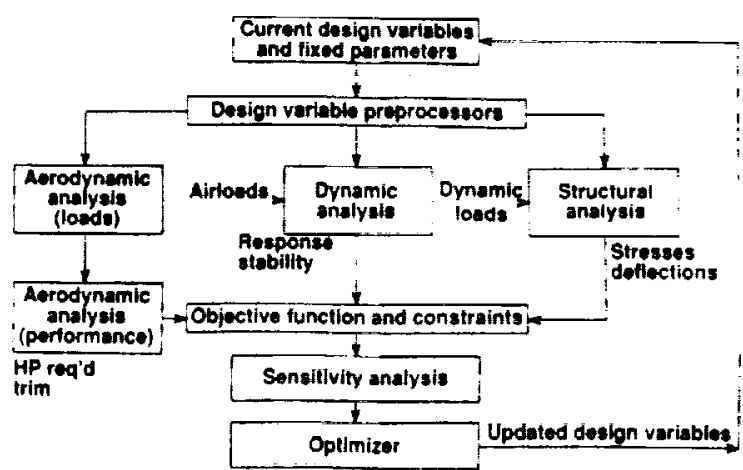

FIg. 4 Integrated aerodynawic-dynawic-structural optinization of rotor blades.

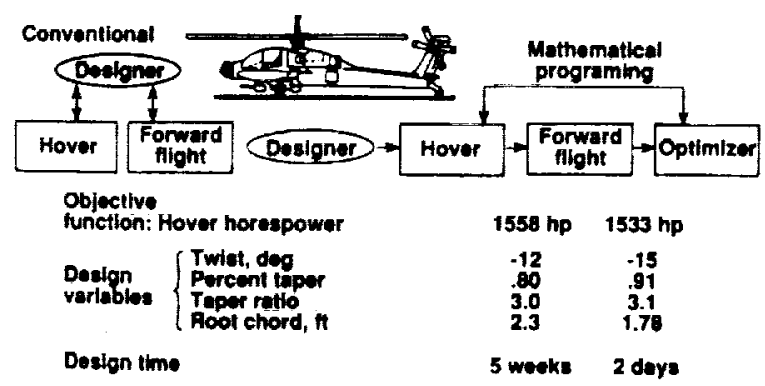

Fig. 5 Results of aerodynamic performance optiolization.

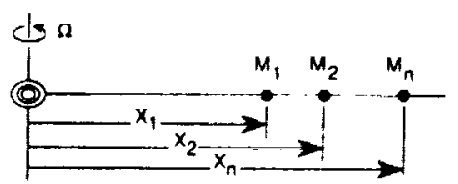

- Deaion goal - Find optimum combination of masses and their locations to reduce blade root vertical shear

- Mothod - Formulate optimization procedure

- Use masses and locations as design variables - Minimize -

- Blade root vertical shear

- Added mass

F1g. 6 Selection of optimum locations of tuning masses for vibration reduction.

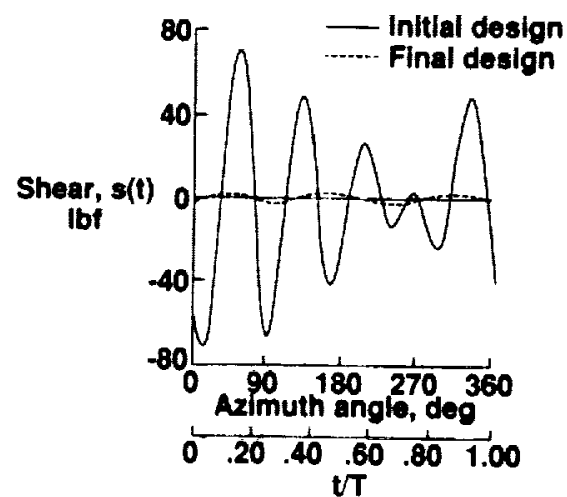

Fig. 7 Time history of vertical root shear miniulzed for 2 modes $/ 3$ harmonics. 


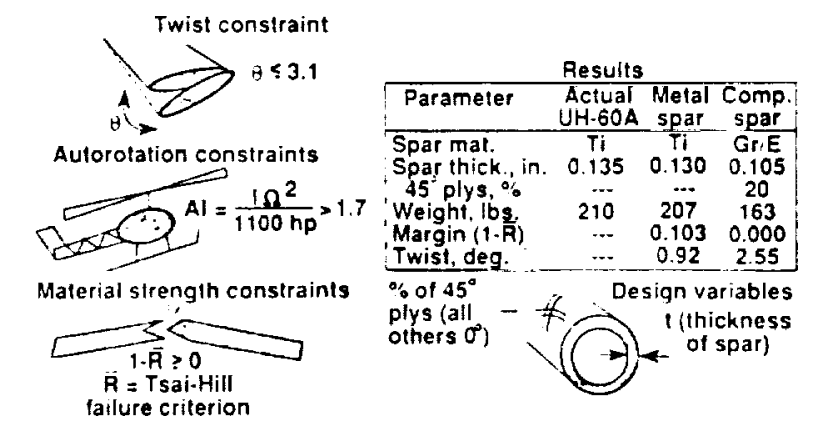

Fig. 8 Structural optimization for minimum welght rotor blades.

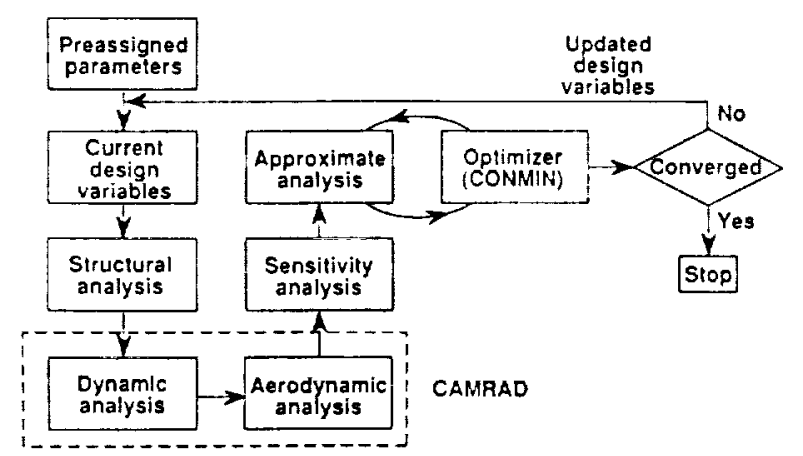

Fig. 9 Flow chart for integrated aerodynamic load/dynamic optimization procedure.

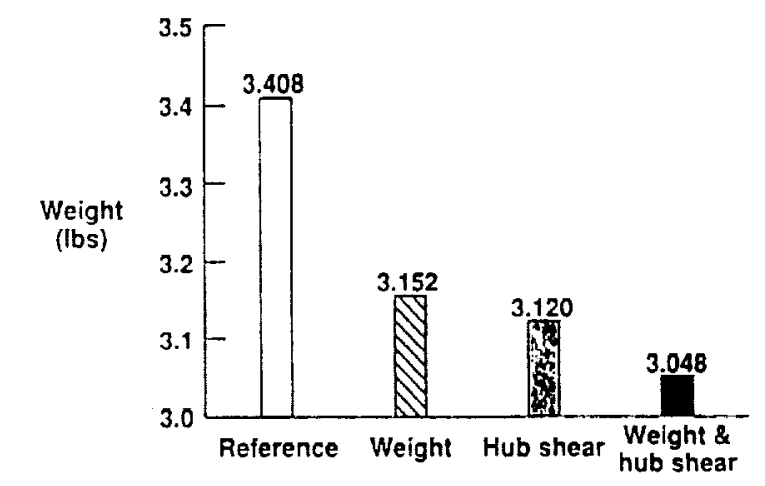

(a) Optimum welght from varlous formularions.

Fig. 10 Results from Integrated aerodynamic load/ dynamic optiolzation procedure.

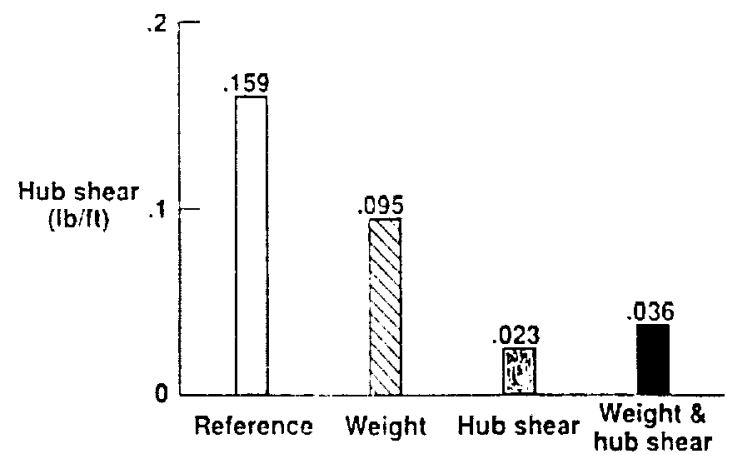

(b) Optimum 4/rev hub shear from various formulations.

Fig. 10 Concluded.

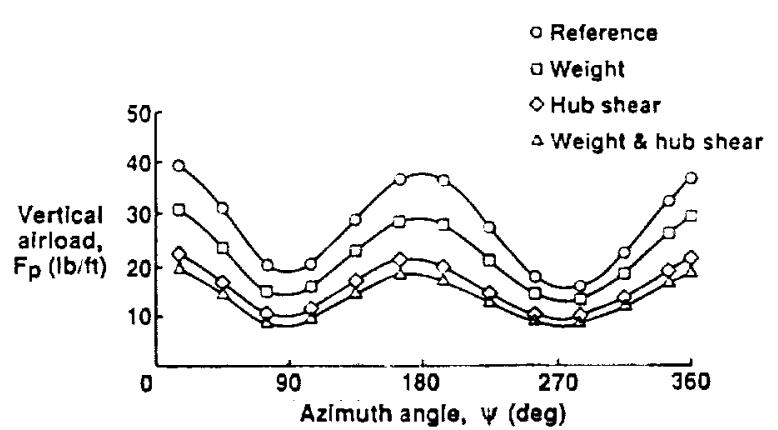

Fig. Il Azimuthal distributions of vertical alrload, $75 \%$ radlus, $\mu=0.3$. 


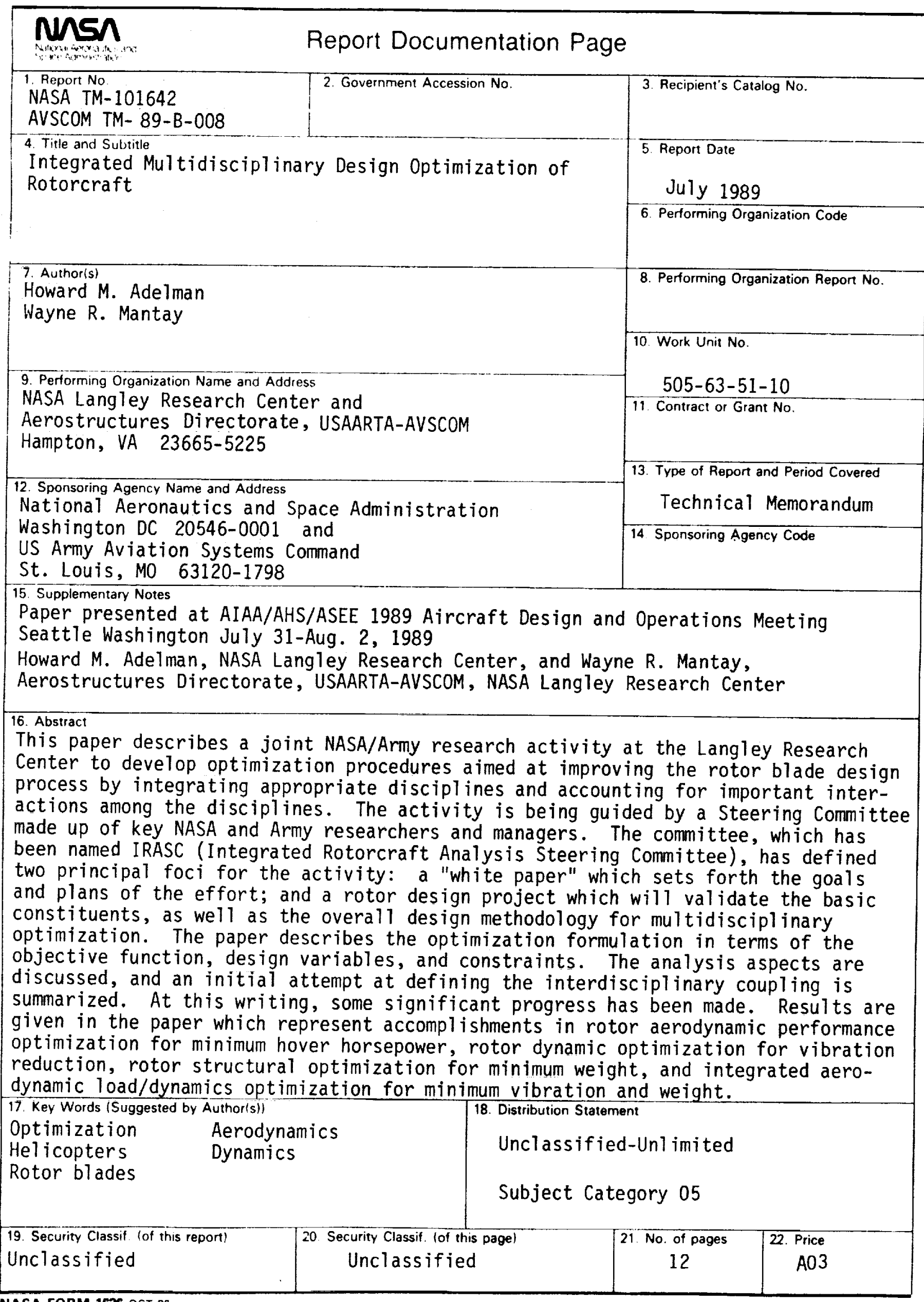

